\title{
CONSTITUTIONAL RIGHTS OF WITNESSES IN FEDERAL GRAND JURY PROCEEDINGS: BURSEY ข. UNITED STATES
}

\author{
Bursey v. United States ${ }^{1}$ is one of several recent cases $^{2}$ defining
} with greater precision the rights of federal grand jury witnesses. Increased litigation reflects in large part the government's extensive use of the grand jury as an instrument systematically to investigate antiwar activists and political dissidents. ${ }^{3}$ Current controversies challenge the traditional image of the grand jury, a secret, freely roving inquiry ${ }^{4}$ by laymen, "unfettered by technical rules," with demands that witnesses be afforded procedural due process and other constitutional protections. ${ }^{6}$

\section{F.2d 1059 (9th Cir. 1972).}

2 E.g., Branzburg v. Hayes, 408 U.S. 665 (1972); Gelbard v. United States, 408 U.S. 41 (1972); United States v. Doe, 460 F.2d 328 (1st Cir. 1972); In re Vericker, 446 F.2d 244 (2d Cir. 1971).

${ }^{3}$ See Donner \& Cerruti, The Grand Jury Network: How the Nixon Administration Has Secretly Perverted a Traditional Safeguard of Individual Rights, THE NaTros, Jan. 3, 1972, at 5; Comment, Federal Grand Jury Investigation of Political Dissidents, 7 Harv. CIV. RIGHTS-CIV. LrB. L. REv. 432 (1972) [hereinafter cited as Grand Jury Investigation].

Grand jury investigations have been given enhanced status and power by the Organized Crime Control Act of 1970, which provides, among other things, for special grand juries called periodically in all major urban areas, 18 U.S.C.A. \$§ 3331-34 (Supp. 1972), for vastly enlarged immunity grants, $i d$. $\$ \$ 6001-03$, and for lower standards of proof for perjury, id. $\$ 1623$. Discussions of sections of the Act may be found in Senate Coman. on the Judictary, Organtzed Crmine Control Act of 1969, S. Rep. No. 617, 91st Cong., 1st Sess. 2-13, 47-59 (1969) [hereinafter cited as Stenate REPORT]; 116 Cong. Rec. 962, 969 (1970) (remarks of Senators Cooper and Hruska); U.S. CopE Cong. \& AD. NEws 4007, 4014-24 (1970). Although the congressional record is devoted almost entirely to discussing the application of these provisions to combat organized crime, in practice they have been used to investigate black, anti-war, and radical activist groups, See, e.g., N.Y. Times, Sept. 8, 1972, at 5, col. 1; id., Sept. 2, 1972, at 21, col. 8.

4 Blair v. United States, 250 U.S. 273, 282 (1919); Hale v. Henkel, 201 U.S. 43, 65 (1906).

5 Costello v. United States, 350 U.S. 359, 364 (1956).

6 The response of courts to claims advanced by grand jury witnesses has been mixed. Recently, the Supreme Court held that requiring newsmen to disclose their confidential sources to a grand jury does not, except in rare cases, abridge the first amendment guarantee of freedom of the press. Branzburg v. Hayes, 408 U.S. 665 (1972); cf. Weinberg v. United States, 439 F.2d 743 (9th Cir. 1971) (absent unusual circumstances, an inhibitory effect on the first amendment right to associate will not justify a refusal by a grand jury witness to testify). See text accompanying notes 105-13 infra. The Supreme Court, however, has held that the fourth amendment protects a grand jury witness from answering questions based on illegal wiretapping of the witness' communication. Gelbard v. United States, 408 U.S. 41 (1972). But cf. Cali v. United States, 464 F.2d 475 (1st Cir. 1972) (grand jury witness not entitled to suppress illegally seized evidence). The ability of the government to grant "use and derivative use" immunity, rather than "transactional" immunity, in order to compel testimony from a witness who claims his fifth amendment right against self-incrimination has been upheld. Kastigar v. United States, 406 U.S. 441 (1972). See In re Vericker, 446 F.2d 244 (2d Cir. 1971); Carter v. United States, 417 F.2d 384 (9th Cir. 1969), cert. denied, 399 U.S. 935 (1970); In re Grand Jury Investigation of Giancana, 352 F.2d 921 (7th Cir.), cert. denied, 382 U.S. 959 (1965). AIthough a grand jury witness has no right to have a lawyer present while he testifies before a grand jury, witnesses have been permitted to consult with counsel outside the grand jury room, but during the proceeding. $C f$. United States v. 
Structurally, the grand jury functions within, and ultimately subject to, the judiciary, even though its role is both investigatory and accusatory. ${ }^{7}$ Generally deferring to the independence of the grand jury and the secrecy of its proceedings, ${ }^{8}$ not until recently have courts intruded into the grand jury room to protect the individual rights of witnesses. " However, "[i]t is the court's process which summons the witness to attend and give testimony, and it is the court which must compel a witness to testify if, after appearing, he refuses to do so."110 This considerable power gives a court the opportunity to oversee and supervise grand juries. It may compel witnesses to testify (or hold them in contempt for not doing so) or may not, if it perceives they are in need of constitutional protection.

Capitalizing on this power to compel process, the Bursey court, in an opinion by Judge Shirley Hufstedler, examined the scope of the rights of grand jury witnesses in three situations: when a prior grant of immunity is insufficient to protect a witness' fifth amendment privilege against compulsory self-incrimination; when "concepts of fundamental fairness inherent in due process require"11 disclosure to a witness of his own grand jury testimony; and when a witness may invoke first amendment protections. Because it resolved each of these issues favorably to the grand jury witnesses, the Ninth Circuit's decision represents an unparalleled attempt to provide procedural and substantive constitutional safeguards in grand jury proceedings. In doing so, the court infused new strength into its supervisory role over the grand jury. Nevertheless, citizens appearing before grand juries, whether as defendants or as witnesses, still do not possess the constitutional protection they have before other arms of the government.

\section{I}

In 1969-1970 Sherrie Bursey and Brenda Joyce Presley were members of the staff of The Black Panther, a weekly newspaper pub-

Corallo, 413 F.2d 1306, 1330 (2d Cir.) cert. denied, 396 U.S. 578 (1969). See generally Calkins, Grand Jury Secrecy, 63 Mirce. L. REv. 455 (1965); Friendly, The Fifth Amendment Tomorrow: The Case for Constitutional Change, 37 U. CIN. L. REv. 671 (1968); Sherry, Grand Jury Minutes: The Unreasonable Rule of Secrecy, 48 VA. L. REV. 668 (1962); Steele, Right to Counsel at the Grand Jury Stage of Prosecution, 36 Mo. L. REv. 193 (1971); Note, Immunity Statutes and the Constitution, 68 CorJur. L. Rev. 959 (1968); Note, Discovery by a Criminal Defendant of his own Grand-Jury Testimony, 68 Corum. L. Rev. 311 (1968); Grand Jury Investigation, supra note 3; Comment, 43 N.Y.U.L. REv. 194 (1968); Comment, Electronic Surveillance of the Grand Jury Witness, 120 U. PA. L. Rev. 546 (1972); Comment, The Federal Witness Immunity Acts in Theory and Practice: Treading the Constitutional Tightrope, 72 Yale L. J. 1568 (1963). 1957).

7 See F. Wharton, Criminal Law and Procedure, $\$ \S 1685$, 1709-10 (Anderson ed.

8 For a discussion of the historic role of the grand jury, see Hale v. Henkel, 201 U.S. 43, 59-60 (1906); In re Russo, 448 F.2d 369, 372-73 (9th Cir. 1972).

9 Grand Jury Investigation, supra note 3 , at 453-54.

10 Brown v. United States, 359 U.S. 41, 49 (1959).

11466 F.2d at 1080. 
lished by the Black Panther Party. During this period the paper printed a nationally reported and televised speech by David Hilliard, Chief of Staff for the Black Panther Party, containing the phrase, "We will kill Richard Nixon." Two subsequent issues of the paper reprinted the speech. Five months later, the paper published an article by Eldridge Cleaver directed "To My Black Brothers in Vietnam" urging them in highly charged language to "quit the Army now or start destroying it from within." 12

A federal grand jury in the Northern District of California began investigating these publications and other activities of the Panthers as possible violations of federal laws generally prohibiting conspiracy, threats against the President, and interference with the armed forces. ${ }^{13}$ Between December 10, 1969, and September 10, 1970, Bursey was called to testify before the grand jury five times, Presley six. Numerous questions were posed to them regarding aspects of the newspaper's production, distribution and personnel, their own life styles, the identities of various party and newspaper staff members, and the financial structure of the party and the paper. ${ }^{14}$

Upon appellants' refusal to answer several of the questions, an application pursuant to section 2514 of the federal criminal code ${ }^{15}$ was filed, requesting immunity for the two witnesses with regard to the grand jury's investigation. Following a hearing, immunity was granted and the witnesses were ordered to answer a specific list of questions. Their fifth amendment privilege against self-incrimination now unavailing, the witnesses claimed a first amendment journalist's privilege of the type that had been granted to reporter Earl Caldwell. ${ }^{16}$ They were found to so qualify, and a protective order issued until and unless the grand jury should show a "compelling and overriding national interest" requiring their testimony. Such interest was subsequently demonstrated to the district court, which ordered Bursey and Presley to answer the previous questions and additionally all other questions relevant to the grand jury's investigation. ${ }^{17}$

When appellants were again questioned, both replied responsively

12 Id. at 1065-67.

$13 I d$. at 1065-66. Under investigation originally were possible violations of 18 U.S.C. $\$ 2$ (1970) (aiding and abetting), id. \& 371 (conspiracy), and $i d . \$ 871$ (threats against the President). The inquiry subsequently extended into areas covered by id. § 1751 (assassination, kidnapping, and assault of the President) and id. § 2387 (interference with armed forces). 466 F.2d at 1065-66.

14.466 F.2d at 1068-71.

1518 U.S.C. $\$ 2514$ (1970) has been repealed by the Organized Crime Control Act of 1970 , Pub. L. No. 91-452, \& 227 (a), 84 Stat. 930, effective four years after the effective date of the Act, which occurred 60 days after its enactment. Id. § 260, 84 Stat. 931-32. It will be replaced by 18 U.S.C. \& 6002 (1970).

18 Caldwell v. United States, 434 F.2d 1081 (9th Cir. 1970), rev'd sub nom. Branzburg v. Hayes, 408 U.S. 665 (1972). In Bursey the witnesses did not directly rely on Caldwell but confronted the court with a different, although analogous, first amendment claim. See text accompanying notes 82-88 infra.

17 In re Grand Jury Witnesses, 322 F. Supp. 573, 578 (N.D. Cal. 1970). 
to a great number of questions but refused to answer several others. At the ensuing contempt hearing, the district court held that all questions were relevant to the investigation and that none of the witnesses' constitutional objections were worthy. They were ordered to answer, and upon their continued refusal to respond, found in contempt.18 The witnesses appealed the contempt conviction, challenging the propriety of the original immunity grant and questioning the constitutionality of the final order to testify.

\section{II}

The court first confronted the question of the proper scope of immunity authorized pursuant to section 2514 . The immunity initially granted was solely in connection with an investigation of possible violations of the federal statute prohibiting presidential assassination, kidnapping, and assault. ${ }^{19}$ The grand jury, however, expanded its inquiry and sought to uncover other violations of federal law. ${ }^{20} \mathrm{Be}$ lieving that to respond might incriminate them for offenses for which they had not been immunized, the witnesses refused to answer some of the questions. The court refused to hold either that immunity goes no further than the questions specifically presented in the court order, or that immunity once granted extends to any and all inquiries by the grand jury. Rather, the scope of immunity was coextensive with the subject matter of the original grant. The burden of showing a minimal standard of relevance was placed on the grand jury. If nothing in the record "suggests a logical connection between the subject of the question and the subject matter of the investigation,"21 then no testimony will be judicially compelled. ${ }^{22}$

This result reasonably flows from the congressional design of the immunity statute. Congress in enacting a predecessor of section $2514^{23}$ desired to avoid immunity grants being given too freely, thereby

$18 I d$.

1918 U.S.C. $\S \S 2,371,871$ (1970). See note 13 supra.

20 Id. \$§ 1751, 2387. See note 13 supra. The prosecution also sought to uncover possible violations of "related statutes," which were never identified. 466 F.2d at 1065-66.

21466 F.2d at 1076.

22 Id. at 1075-76. Cited for authority in the opinion is a long list of cases, none of which is directly on point. Later, the government argued that the court's requiring that questions propounded by the grand jury be related to the subject matter of the immunity grant was contrary to prior authority. Id. at 1091 (opinion on petition for rehearing and suggestion for rehearing en banc). Although rejecting this contention, Judge Hufstedler seemed aware of the lack of precise precedential support for her holding. Compare id. at 1075, with id. at 1091 (treatment of Carter v. United States, 417 F.2d 384, 388 (9th Cir. 1969), cert. denied, 399 U.S. 935 (1970)). The court, however, found compelling the reasoning of Chief Judge Friendly in In re Vericker, $446 \mathrm{~F} .2 \mathrm{~d} \mathrm{244,247-48}$ (2d Cir. 1971). The persuasiveness of Friendly's opinion is subject to dispute within the Ninth Circuit itself. Compare 466 F.2d at 1091, with In re Russo, 418 F.2d 369, 372-74 (9th Cir. 1971).

23 Id. at 1073-74 n.5, 1075. The court specifically looked to Act of Aug. 20, 1954, ch. $769, \S 1,68$ Stat. 745 (formerly codified at 18 U.S.C. $\$ 3486(\mathrm{c})$ (1964)) (repealed 
hindering future prosecution. ${ }^{24}$ Therefore, it was provided that the United States Attorney must conclude that the immunity is necessary to the public interest and additionally receive the approval of the Attorney General before requesting the court to grant immunity. ${ }^{25}$ The grand jury was presumed to have neither a sufficiently detached perspective nor the requisite expertise. In this scheme, it was the court's duty to be one of "at least two other independent but interested parties who must concur in the grant of immunity."20 Moreover, section 2514 permitted immunity to be granted only for offences specifically enumerated in section $2516 .^{27}$ Although in recent years, the federal immunity umbrella has grown to encompass more and more offenses ${ }^{28}$ the basic statutory pattern remained unaltered at the time of Bursey's contempt hearing. Because Congress limited the availability of immunity in this fashion, it was the court's task to ensure that questions asked of the witnesses were not irrelevant to a permissible grant of immunity. ${ }^{29}$

Although the device of going to a judge to ascertain the scope of immunity kept Bursey and Presley from being cited for contempt and generally safeguards witnesses' fifth amendment rights against self-incrimination, it does not protect against overly-broad investigations of dissident types. The court's ruling might merely encourage applications with the conclusory language that immunity is requested in connection with an investigation of a federal offense enumerated in section 2516 of the federal criminal code. ${ }^{30}$ Alternatively, a later filing naming additional offenses could be submitted to the court. A minimal increment in the procedural protection of a witness' first amendment interests is the most that can be expected from this rule. This is not

by Organized Crime Control Act of 1970, Pub: L. No. 91-452, § 228(a), 84 Stat. 930), as a model for $\$ 2514$ and considered the former's legislative history persuasive.

24 H.R. REP. No. 2606, 83d Cong., 2d Sess. 5 (1954).

25 Both $\$ 2514$ and $\$ 3486$ (c) contain this requirement.

26466 F.2d at 1075, quoting H.R. Rep. No. 2606, 83d Cong., 2d Sess. 8 (1954).

2718 U.S.C. $\$ 2516$ (1970). Section 2514 also permits immunity grants to be given for any proceeding "involving any violation of this chapter," that is, wire interception and interception of oral communications. Id. $\$ 2514$. inclusion.

$28 \mathrm{Id}$. $\$ 2516$ (1) (c). A note following $\S 2516$ lists the offenses and the years of their

29 The extent and scope of the court's role when hearing an immunity application pursuant to $\$ 2514$ are not at all settled. Compare In re Evans, 452 F.2d 1239, 1250-51 (D.C. Cir. 1971); In re Vericker, 446 F.2d 244, 247-48 (2d Cir. 1971), with United States v. Neiberger, 460 F.2d 290, 291-92 (6th Cir. 1972); In re Russo, 448 F.2d 369, $371-72$ (9th Cir. 1971) (reaffirming Licata v. United States, 429 F.2d 1177 (9th Cir.), vacated as moot, 400 U.S. 938 (1970)).

Even assuming, however, that the issuance of a $\$ 2514$ immunity order by the court is a ministerial act, this does not mean that at a contempt hearing subsequent to the witness' refusal to answer questions, the court may not independently determine whether questions are related to the grant of immunity. In the latter situation, there will most likely be more need for judicial protection, and the reasons given by the Bursey court in support of its holding make sense.

3018 U.S.C. $\$ 2516$ (1970). Section 2516's enumeration.of federal offenses will no longer be relevant for purposes of obtaining an immunity grant when $\S 2514$ 's repeal becomes effective. Note 15 supra. 
a great gain ${ }^{31}$ especially when weighed against the danger of broadlyworded affidavits and further delays caused by additional hearings.

Although the court's statutory interpretation of section 2514 and its earlier version is perhaps correct as of the time of their enactment, unfortunately it will not stand up over time. It seems incongruous to be bound by Congress' intent when it enacted the predecessor of section $2514,{ }^{32}$ because at present both of these sections have been repealed. Section $6003,{ }^{33}$ granting only "use and derivative use" immunity, will become effective in December, 1974 and "for the first time provide for compelling testimony in proceedings involving any violation of federal law." "34 Moreover, it makes clear that the court has no discretion to deny an immunity application. ${ }^{35}$ While the United States Attorney will still be obligated to itemize for the court the offenses for which he seeks immunity, given his absolute discretion and the fact that the statute encompasses all federal offenses, nothing prevents him from submitting an exhaustive list of crimes in connection with which a witness can be forced to testify.

The attempt in Bursey to confine through statutory interpretation the compulsion of testimony under a grant of immunity to "the subject matter for which [the witness] has been immunized"36 seems a vain assertion of judicial authority in the face of recent, and antagonistic, congressional action.

\section{III}

Secondly, the court attempted to cure some of the unfairness inherent whenever a grand jury repetitively asks the same or similar questions. $^{37}$ In such a situation, it was held, no contempt order for refusal to answer will be sustained unless the witness has been permitted to inspect his prior testimony, if recorded. Should the grand jury, however, meet its substantial burden of showing that exceptional circumstances warrant secrecy, then disclosure will be limited to an

81 It should be noted, however, that as immunity is broadened with expanded questioning so is the witness' fifth amendment privilege. Indeed some grand jury witnesses might enjoy and desire as extensive an immunity grant as possible.

32 See note 22 supra.

3318 U.S.C. $\$ 6003$ (1970). See note 15 supra.

84 Senate Congor. on the Judictary, Organized Crine Controt Act of 1969, S. REP. No. 617, 91st Cong., 1st Sess. 107 (1969) (comments of Department of Justice).

$\mathbf{3 5}$ "The court's role in granting the order is merely to find the facts on which the order is predicated." H.R. REP. No. 1549, 91st Cong., 2d Sess. 43 (1970). Compare 18 U.S.C. $\$ 6003$ (a) (1970), with id. \$ 2514 (repealed, effective Dec. 1974, by the Organized Crime Control Act of 1970, Pub. L. No. 91-452, § 227 (a), 84 Stat. 930).

30466 F.2d at 1076.

37 The Ninth Circuit also reversed that part of the contempt order based upon Bursey's refusal to answer questions that had been originally excepted by the district court from the immunity application. It was clear to the court that the concept of due process gave the witness the right to rely upon an earlier exception in the immunity grant, until the "reversal of that order... has been brought to the witness' attention with unmistakable clarity." Id. at 1081. 
in camera inspection. At this juncture, "if it appears that the witness, in substance, may have answered the questions for which compulsory process is sought, the court must disclose such passages in the prior testimony to the witness and his counsel."38 The witness could then avert a contempt citation by either repeating his former testimony or calling it to the grand jury's attention. ${ }^{39}$

To reach this result the court balanced the interests of the grand jury against adverse effects on the witnesses. Repetitively asked questions cannot produce any significant amount of information not already possessed by a grand jury. Of course any investigatory body has a legitimate need to examine a witness' demeanor and consistency in answering. This is not to say, however, that questions can be repeated without limit. "Excessive repetition .... needlessly prolongs an investigation, and it may permit abuse of the witness." 40 A witness would then be exposed to the potential risks of perjury or of inadvertently waiving his first or fifth amendment rights, especially when, as in Bursey, the interrogations are separated by months of time. ${ }^{41}$

The court's approach is consistent with the "growing realization that disclosure, rather than suppression, of relevant materials ordinarily promotes the proper administration of justice." ${ }^{22}$ Although "wholesale" 43 disclosure of grand jury testimony has not been tolerated, on recognized occasions, when reasons for secrecy are nonexistent, disclosure is appropriate. ${ }^{44}$

On balance, this is such an occasion. Four principal reasons for grand jury secrecy are traditionally set forth:

(1) To prevent the accused from escaping before he is indicted and arrested or from tampering with the witnesses

38 Id. at 1080.

39 The procedure adopted by the court was modelled after FED. R. CRIM. P. 16(a), which authorizes a court to permit a defendant access to his own recorded grand jury testimony. In United States v. Projansky, 44 F.R.D. 550 (S.D.N.Y. 1968), the court held that rule 16(a) conferred a nearly automatic right of the defendant to his own testimony, and that this testimony should be routinely available to the defendant, absent a showing of need for secrecy by the government. Accord, United States v. Manetti, 323 F. Supp. 683 (D. Del. 1971); see ABA Spectas Comam. on Federal Rules of PROCEDURE, 38 F.R.D. 95, 106 (1965).

40466 F.2d at 1079.

41 Id. at 1079-80.

42 Dennis v. United States, 384 U.S. 855, 870 (1966).

43 United States v. Procter \& Gamble Co., 356 U.S. 677, 683 (1958).

44 Some of the recognized exceptions are the following: Dennis v. United States, 384 U.S. 855 (1966) (impeachment purposes at trial); United States v. Thoreson, 428 F.2d 654 (9th Cir. 1970) (witness expecting later to be a defendant in a grand jury proceeding may have his testimony recorded); Cargill v. United States, 381 F.2d 849 (10th Cir. 1967), cert. denied, 389 U.S. 1041 (1968) (disclosure proper when defendant prosecuted for perjury); United States v. Youngblood, 379 F.2d 365 (2d Cir. 1967) (defendants as a matter of circuit court rule are entitled to the grand jury testimony of all witnesses called at trial, absent unusual circumstances); United States v. American Radiator \& Standard Sanitary Corp., 288 F. Supp. 701 (W.D. Pa. 1968) (government witness may refresh his memory from his testimony before the grand jury); United States v. Rosenberg, 39 F.R.D. 301 (S.D.N.Y. 1966) (perjury). 
against him. (2) To prevent disclosure of derogatory information presented to the grand jury against an accused who has not been indicted. (3) To encourage complainants and witnesses to come before the grand jury and speak freely without fear that their testimony will be made public thereby subjecting them to possible discomfort or retaliation. (4) To encourage the grand jurors to engage in uninhibited investigation and deliberation by barring disclosure of their votes and comments during the proceedings. ${ }^{45}$

Disclosure of questions propounded arguably could tip off potential defendants who then could escape or tamper with witnesses. Ordinarily, however, a witness before the grand jury is under no obligation of secrecy. ${ }^{46}$ If a future accused is a friend, the witness could warn him with or without the transcript. If, on the other hand, the accused is a person who might harm the witness, there is no reason to suppose a witness would act so adversely to his own interest as to reveal his knowledge of this man's identity, whether or not a transcript were available. Likewise, a name mentioned during the proceedings could conceivably implicate an innocent person. Once again, a witness is free to mention this person's name, even without a transcript. ${ }^{47}$ Disclosure will not prevent witnesses from speaking more openly, because, in this situation, they have already answered identical questions and simply desire to avoid commiting perjury. No request was made for access to the grand jury's deliberations or voting. ${ }^{48}$ Anything revealing a sensitive topic or embarrassing to the jurors could always be excised from the record during an in camera hearing. There is no reason not to allow the grand jury witness access to his own testimony when the justifications for secrecy do not stand up. This result is especially compelling if the suggestion by Wigmore is accepted that the beneficiary of the rule of secrecy was intended to be the witness himself. ${ }^{40}$ It is nonsensical to apply any rule to the detriment of its intended beneficiary.

The advantages of a witness' having a copy of his own grand jury testimony are considerable, ${ }^{50}$ and extend beyond avoiding repetitive

45 Pittsburgh Plate Glass Co. v. United States, 360 U.S. 395, 405 (1959) (Brennan, J., dissenting).

46 FED. R. CRMM. P. 6(e) binds every participant in grand jury proceedings to secrecy except the witness by stating "[n]0 obligation of secrecy may be imposed upon any person except in accordance with this rule." $I d$. The note prepared by the Advisory Committee on Rules following rule 6 is more specific: "(2) The rule does not impose any obligation of secrecy on witnesses."

47 Cf. In re Russo, 53 F.R.D. 564, 572 (C.D. Cal. 1971).

48 In no event can there be disclosure of the grand jury's deliberation or of its votes, as these are not even revealed to the government. FED. R. CRTM. P. 6 (e).

$498 \mathrm{~J}$. WigMrore, EVIDENCE \& 2362 (MCNaughton ed. 1961).

50 See Grand Jury Investigation, supra note 3, at 473-94. It should be mentioned that some witnesses may not desire their testimony to be transcribed, because without a written record of what they said, they could not later be prosecuted for perjury as a result of inconsistent in-court statements. 
questioning. A witness could correct errors which inevitably arise through transcription. ${ }^{51}$ If a witness knew with reasonable certainty that he might later be indicted, ${ }^{52}$ a copy of his testimony would help his attorney prepare for trial. ${ }^{53}$ In situations in which the grand jury's investigation advances into topics not enumerated in an immunity application, the transcript will be an essential element in a later court determination whether a witness' testimony was immunized. ${ }^{54}$

The court's opinion, however, did not analyze the problem so broadly, but rather focused on the narrower issue of repetitive questioning. Without explicitly doing so, the court seemed to require a showing of particularized need, ${ }^{55}$ by presuming that being repeatedly asked the same questions demonstrated that need. Bursey, then, would permit witnesses access to their testimony in a limited number of cases and only when a contempt citation was sought. In re $R u s s 0^{56}$ presented a somewhat similar factual situation but offered a less restrictive approach to disclosure. Russo, previously adjudged guilty of contempt for refusing to answer a grand jury's questions, ${ }^{57}$ promised to testify further before the grand jury if he would be allowed a copy of his earlier grand jury testimony. Analyzing the reasons for grand jury secrecy, ${ }^{58}$ the court could "conceive of no reason why furnishing a witness a written transcript of his testimony should interfere with the valid functions of the grand jury." jury secrecy in substantial part was bottomed on the need to protect witnesses, it was senseless to require from a witness a showing of

51 Cf. In re Russo, 53 F.R.D. 564, 571-72 (C.D. Cal. 1971).

52 This raises the question whether it is ever proper to call as a witness before the grand jury a person who will most likely be a defendant. Compare Jones v. United States, 342 F.2d 863 (D.C. Cir. 1964) (en banc), with United States v. Scully, 225 F.2d 113, 116 (2d Cir.) (Frank, J., concurring), cert. denied, 350 U.S. 897 (1955).

53 E.g., United States v. Thoreson, 428 F.2d 654, 666 (9th Cir. 1970); cf. In re Russo, 53 F.R.D. 564, 571 (C.D. Cal. 1971).

54 As the new immunity statute, 18 U.S.C. \& 6002 (1970), takes complete effect, this protection should not be undervalued. In a prosecution subsequent to the time when testimony was compelled after a grant of "use and derivative use" immunity,

'To]nce a defendant demonstrates that he has testified, under a state grant of

immunity, to matters related to the federal prosecution, the federal authorities

have the burden of showing that their evidence is not tainted by establishing

that they had an independent, legitimate source for the disputed evidence.'

Kastigar v. United States, 406 U.S. 441, 460 (1972), quoting Murphy v. Waterfront Comm'n, 378 U.S. 52, 79 n.18 (1964). For a witness later to make this liminal demonstration it is essential that he have access to his grand jury testimony.

55 In treating the problem in this manner, the court may have been influenced by the requirement that a defendant must show "particularized need" for discovery of his grand jury testimony, a requirement established in United States v. Procter \& Gamble Co., 356 U.S. 677, 683 (1958), and Pittsburg Plate Glass Co. v. United States, 360 U.S. 395,400 (1959). Although the standard was somewhat liberalized in Dennis v. United States, 384 U.S. 855, 872-73 (1966), it remains for most federal courts the accepted norm. Boudin, The Federal Grand Jury, 61 GEo. L.J. 1, 30-34 (1972).

5653 F.R.D. 564 (C.D. Cal. 1971).

67 In re Russo, 448 F.2d 369 (9th Cir. 1971).

5853 F.R.D. at 568-72. The court's analysis was substantially similar to that presented at text accompanying notes $45-49$ supra.

59 Id. at 571. 
particularized need. " $\mathrm{He}$ must show only that his testimony was recorded and a transcript can be made." ${ }^{\circ 1}$ Nevertheless, a contempt proceeding remains as essential to trigger the court's supervisory power. ${ }^{62}$

Substantial procedural and substantive obstacles still confront the witness. Because no circuit requires grand jury testimony to be recorded, a witness would before testifying need to bring a motion forcing the grand jury to transcribe its proceedings. In the event his transcript was necessary to defend a later contempt charge, he would have to make another motion to grant access to the transcript. Under Bursey, only if the witness demonstrated that the questioning offended the notion of fundamental fairness inherent in the due process clause would he prevail.

Arguments against secrecy and in favor of disclosure apply beyond the facts in either Bursey or Russo and indicate that a grand jury witness, absent a showing by the government that secrecy is required for reasons of national security, ${ }^{83}$ should always be granted access to his testimony. Implicit in such a proposal is the requirement that all grand jury proceedings must be recorded and transcribed. Mandatory transcription, although neither compelled by the Constitution, ${ }^{64}$ by statute, ${ }^{65}$ or by court rule, ${ }^{68}$ has long been considered the better practice. ${ }^{67}$ Indeed, twice the American Bar Association's Special Committee on Federal Rules of Procedure has recommended its adoption. ${ }^{68}$ States which prescribe mandatory transcription ${ }^{69}$ do not seem to have grand juries which operate any less effectively. ${ }^{70}$ Reasons given in support of

$60 I d$. at 572-73 (discussing United States v. Procter \& Gamble Co., 356 U.S. 677, $682(1958))$.

$01 \mathrm{Id}$.

62 Because the court simply held that the witness was purged of civil contempt by his promise to testify if furnished with a transcript, it avoided the necessity of interpreting the language of FED. R. CRJM. P. 6(e), which states that a court can order disclosure "preliminary to or in connection with a judicial proceeding." 53 F.R.D. at 572 .

63 In such a situation, the accommodation tendered by the Bursey court of an in camera inspection with limited disclosure should be implemented, if warranted. See text accompanying notes 37-39 supra.

04 E.g., Schlinsky v. United States, 379 F.2d 735, 740 (1st Cir.), cert. denied, 389 U.S. 920 (1967) ; United States v. Cianchetti, 315 F.2d 584, 591-92 (2d Cir. 1963); cf. McCaffrey v. United States, 372 F.2d 482, 484 (10th Cir.), cert. denied, 387 U.S. 945 (1967); Welch v. United States, 371 F.2d 287, 294 (10th Cir.), cert. denied, 385 U.S. 957 (1966).

65 Cf. FED. R. CRTor. P. 6(d) states that "a stenographer or operator of a recording device may be present while grand jury is in session," clearly implying that one need not be present, and that therefore transcription is within the court's discretion.

66 E.g., United States v. Aloisio, 440 F.2d 705, 708 (7th Cir.), cert. denied, 404 U.S. 814 (1971) (collecting cases).

67 Compare United States v. Cramer, 447 F.2d 210, 213-14 (2d Cir. 1971), cert. denied, 404 U.S. 1024 (1972), with id. at 221 \& n.1 (Oakes, J., dissenting).

68 ABA Spectal Cotar. on Federal Rules of Procedure, Report, Appendix, 52 F.R.D. 87, 94-95 (1971); id., 38 F.R.D. 95, 106 (1965).

69 E.g., CaLtF. Penal Code $\$ 938.1$ (West Supp. 1972); Iowa Code ANN. \$ 772.4 (1950); K女. Rev. Stat. § 5.16 (1969); MinN. StaT. ANN. \& 628.04 (1947).

70 Calkins, Grand Jury Secrécy, 63 MrcH. L. Rev. 455, 466 n.42 (1965); 48 CALTF. L. REv. 160, 161-62 (1960). See generally Kennedy \& Briggs, Historical and Legal Aspects of 
mandatory transcription, however, emphasize the benefits to the defendant, not the witness. ${ }^{71}$ Once a transcript has been made, the related arguments in support of allowing witnesses access to their own testimony should prevail. ${ }^{72}$ California now makes public, subject to certain limitations, transcripts of grand jury proceedings seemingly without hindering its purpose of discovering criminal activity. ${ }^{73}$ Because the gain in procedural fairness far outweighs any loss in grand jury effectiveness, ${ }^{74}$ the federal circuit courts should by rule require mandatory transcription and recordation of grand jury proceedings. ${ }^{75}$ Because the reasons for secrecy are inapposite whenever a grand jury witness seeks a copy of his own testimony, courts should permit him access to it, absent countervailing interests of national security.

\section{IV}

Finally, society's need for effective grand juries was balanced against their alleged infringement of witnesses' and the public's first amendment liberties. The precise issue before the court was whether two grand jury witnesses, members of the staff of the official newspaper of the Black Panther Party, could be compelled to answer questions basically concerning the identities of members and the operations of both the newspaper and the party in connection with a grand jury investigation into possible crimes related to or growing out of a speech by David Hilliard, a leader of the Black Panther Party.

The Government first contended that the first amendment did not protect the witnesses' refusals to testify because they were connected with threats to the President and calls for disloyalty in the armed forces, both of which were conduct, not speech ${ }^{76}$ However, the issue whether Hilliard's speech, Cleaver's article, or any actions related to them fell within the relevant statutory proscription requiring specific intent, was precisely the subject of the grand jury's inquiry. The Government had assumed the conclusion and this logical inconsistency in its position justified the court's rejecting it. Moreover, the Government advanced from the incorrect presumption that expressions are not protected, unless proved otherwise; the burden is on the state to show that any possibly criminal activities were outside the first amendment's protec-

the California Grand Jury System, 43 CAxIF. L. Rev. 251 (1955); Louisell, Criminal Discovery: Dilemma Real or Apparent?, 49 CALIF. L. REv. 56 (1961).

71 E.g., United States v. Cramer, 447 F.2d 210, 221 (2d Cir. 1971), cert. denied, 404 U.S. 1024 (1972) (Oakes, J., dissenting).

72 See text accompanying notes 50-60 supra.

73 CartF. Penal Code § 938.1(b) (West Supp. 1972).

74 Cf. United States v. Gramolini, 301 F. Supp. 39, 41-42 (D.R.I. 1969).

75 Cf. United States v. Youngblood, 379 F.2d 365, 369-70 (2d Cir, 1967) (prospective rule that in all cases, absent a threat to national security interests defendants are permitted as a matter of right to examine the grand jury testimony of witnesses who testify at trial).

76466 F.2d at $1081-82$. 
tion. Placing this burden of proof on the government is consistent with past precedents ${ }^{77}$ and recognizes the importance of first amendment values in a free society. ${ }^{78}$

Next, it was argued the first amendment did not apply in the grand jury room. ${ }^{79}$ No reason or precedent ${ }^{80}$ supported such an argument. Constitutional safeguards exist to protect citizens from unwarranted governmental intrusions in whatever form they take. The correct question was the proper accommodation, given the role of the grand jury in our jurisprudence, between the government's need for information and any inhibitory effects on the exercise of first amendment rights. The court looked to judicial standards enunciated in the context of legislative investigation cases for help in harmonizing the conflicting interests before it. ${ }^{81}$ In those cases, the Government had the burden of showing an "immediate, substantial, and subordinating" interest in the subject matter under investigation and a substantial connection between it and the information sought. Moreover, it must demonstrate that there exist no less drastic means of achieving valid governmental goals. Finally, the government must conduct a "step by step" investigation, laying as it advances an adequate foundation for its questions.

Such a test was demanded for witnesses before a grand jury, the court reasoned, because of the interests of a free press, threatened by questions delving into the affairs of the newspaper. A free press, vital to a democratic society, must have the freedom "to decide what to print and to distribute what is printed." ${ }^{282}$ Essential, also, is the right to publish anonymously. Additionally, the exercise of associational rights, ${ }^{83}$ not only by the two litigants but by all those who might affiliate with the groups in question, was constrained by questions designed to educe the

77 Id. at 1083. The court relied on the following cases: In re Stolar, 401 U.S. 23 (1971); United States v. O'Brien, 391 U.S. 367,377 (1968); DeGregory v. Attorney General, 383 U.S. 825 (1966); Shelton v. Tucker, 364 U.S. 479 (1960).

78 E.g., Bantam Books, Inc. v. Sullivan, 372 U.S. 58, 66 (1963); Bates v. City of Little Rock, 361 U.S. 516, 523 (1960); NAACP v. Alabama, 359 U.S. 449, 461 (1958).

79466 F.2d at 1082.

80 To the contrary, the Supreme Court has expressly recognized that the first amendment is not nugatory in grand jury proceedings: "We do not expect courts will forget that grand juries must operate within the limits of the First Amendment as well as the Fifth." Branzburg v. Hayes, 408 U.S. 665, 708 (1972) (plurality opinion).

81466 F.2d at 1083. The court looked specifically at Gibson v. Florida Legislative Investigation Comm., 372 U.S. 539, 551, 557 (1963) and Shelton v. Tucker, 364 U.S. 479, 487-90 (1960), for guidance in devising an appropriate standard. See text accompanying notes $91-98$ infra.

$82 \mathrm{Id}$. at 1084-85.

83 The question whether associational interests, standing alone, could ever outweigh the legitimate interests of the grand jury in investigating criminal conduct has never been squarely decided. In United States v. Weinberg, 439 F.2d 743, 747-48 (9th Cir. 1971), the court, under the facts of that case which involved only the future chilling effect on the witnesses' right of associational privacy, struck a balance against the first amendment. The court, however, did leave open the limited possibility that "unusual circumstances," such as those in Caldwell v. United States, 434 F.2d 1081 (9th Cir. 1970), rev'd sub nom., Branzburg v. Hayes, 408 U.S. 665 (1972), might justify upholding a witness' refusal to testify where first amendment interests were threatened. See 466 F.2d at 1082 n.15. 
identity of the witnesses' newspaper colleagues and of Black Panther Party members.

By quoting extensively from Talley $v$. California, ${ }^{84}$ the opinion appeared to place its greatest reliance on the need to publish anonymously. In Talley the Supreme Court invalidated an ordinance forbidding the distribution of handbills unless the names and addresses of the authors, printers, publishers, and distributors were printed on them because the ordinance's application was broader than necessary to achieve any valid governmental objective. ${ }^{85}$ Under those circumstances, the Court held that requiring the disclosure of the identities of the pamphleteers would inhibit the freedom to distribute information. The opinion continued and proclaimed in sweeping terms that the ability to publish anonymously was essential to a free society. The repressive effect in Talley was largely due to the fact that the governmental action in question was an ordinance, which broadly prevented groups from informing the public through the medium of handbills of their ideas.

A particularized grand jury investigation into possible crimes which demanded the identities of members of a group would at first blush seem to affect in a less stifling fashion the freedom to publish anonymously. There is, however, an additional first amendment interest more threatened in Bursey than in Talley. Closely linked to the freedom to publish anonymously are first amendment associational interests. ${ }^{86}$ Groups with a need to publish anonymously are usually those espousing unpopular, minority beliefs. To ask them to reveal their membership might cause them to lose old members and fail to attract new ones for fear of private reprisals or government harassment. ${ }^{87}$ The concept of liberty includes within it the right of citizens to affiliate with each other for the purpose of disseminating ideas. Protecting privacy of association is essential to ensure that the exercise of this right will not be deterred. ${ }^{88}$ Disclosure to the grand jury has more of an inhibitory effect than a Talley ordinance because in the latter case no names would be revealed

84362 U.S. 60 (1960).

85 The Supreme Court rejected California's argument that the ordinance was necessary to prevent fraud, false advertising, and slander by noting that those evils could be directly probibited. $I d$. at 64 .

86 The court found support for its analysis in a series of cases dealing with various legislative attempts to obtain information about the National Association for the Advancement of Colored People and other similar groups. Gibson v. Florida Legislative Investigation Comm., 372 U.S. 539 (1963); Shelton v. Tucker, 364 U.S. 479 (1960); Bates v. City of Little Rock, 361 U.S. 516 (1960); NAACP v. Alabama, 357 U.S. 449 (1958).

87 A significant part of the chilling effect perceived in Gibson and NAACP v. Alabama was the threat of private reprisals once the information was in the government's hands. The fact that the issue of private reprisals was not raised in Bursey, however, does not settle the question whether the first amendment interests need protection. $C f$. NAACP v. Alabama, 357 U.S. 449, 463 (1958). Possession by the government of information about a group is usually sufficient to inhibit the exercise of first amendment rights. See text accompanying note 92 infra.

88 E.g., Bates v. City of Little Rock, 361 U.S. 516, 523 (1960); NAACP v. Alabama, 357 U.S. 449,462 (1958). 
until the group used handbills to communicate to the public. Although the group might be less effective, it could continue other activities without governmental interference or supervision, and if it chose to take the risk, could even distribute handbills without complying with the ordinance. Additionally, the entire membership list would not be in the government's hands. Nevertheless, the Supreme Court found that even this amount of disclosure was too high a price for the government to exact, absent a convincing justification, for the exercise of constitutional rights. If the government prevailed in Bursey, the occasion of grand jury questioning would grant the government access to the identities of all persons on the newspaper staff and of the Black Panther Party.

Looking to the government's interest, it goes without saying that the state has a compelling interest in detecting crime through the grand jury. However, merely to assert the proposition ought not to be enough to outweigh the burden on first amendment rights caused by certain questioning. The protection of the first amendment interests by the test formulated in Bursey should only be rejected if the loss in the grand jury's effectiveness, operating with the test, is substantial. ${ }^{80}$ Without the test the grand jury would surely receive answers to its questions more rapidly, thereby gaining efficiency. But it would have in its possession no more information, useful to its investigation, than it could have obtained pursuant to the Bursey test, because if the information is useful, then one may safely assume that the grand jury could have made the necessary showing. Although information sought may be useful for purposes not germane to the specific investigation, receiving such information in this manner is not a governmental interest worthy of protection. ${ }^{90}$

The Ninth Circuit did not question whether the test from the legislative investigation cases was appropriate for grand juries. Although both are governmental investigative bodies, they differ in how they perform that function..$^{91}$ First, legislative committees investigate publicly while grand juries proceed in secrecy. Public exposure was thought to be a major source of the legislative committee's inhibitory effect on first amendment interests. ${ }^{92}$ Answering this argument, Judge Hufstedler reasoned that, under the facts in Bursey, the government's possession of information similarly chilled the witnesses' first amendment rights. Those circumstances involved a minority political party and its official newspaper, both strongly critical of governmental policies. What was

80 See generally Note, Less Drastic Means and the First Amendment, 78 Yale L.J. 464 (1969).

90 Cf. Branzburg v. Hayes, 408 U.S. 665, 700 (1972), quoting DeGregory v. Attorney General, 383 U.S. 825, 829 (1966).

01 See Grand Jury Investigation, supra note 3 , at 477-81.

92 E.g., Shelton v. Tucker, 364 U.S. 479, 486-87 (1960); Bates v. City of Little Rock,

361 U.S. 516, 523-24 (1960) ; NAACP v. Alabama, 357 U.S. 449, 462-63 (1958). 
asked was the identities of members of both associations before any foundation existed to believe that that knowledge would assist in uncovering a crime. The threat to first amendment interests caused by only the government's possessing the information can be seen by imagining that the government required this party to register on the grounds that it was considered subversive. No one would doubt that strong justification would be needed to legitimate such action. Absent that strong showing, the government should not be able to achieve the same result indirectly. Of course should the government demonstrate that the information would help unearth a crime, the test propounded in Bursey would grant the grand jury access to it.

The First Circuit was invited in United States v. Doe, to apply the legislative standards to grand juries where questions abridged a scholar's first amendment interest in gathering information. ${ }^{93}$ The court declined to extend the analogy primarily for the reason that because the two bodies carry out their investigating duty in different manners and for different purposes, different standards of relevance apply. The legislative committee test was needed to protect individuals from being forced to answer questions too particularized to be of any aid in solving the general problem before the legislature. So that questions bearing no relation to the passing of a law not be asked, the Supreme Court required a showing of relevance to the legislative purpose. On the other hand, a grand jury must determine "if there is probable cause to believe that particular crimes have been committed by particular persons." ${ }^{\prime 4}$ Because its inquiry is finer, it can legitimately expect responses to specific, detailed questions. To ask the grand jury to make a showing of relevancy would check its traditionally broad discretion to decide its needs. That grand juries need flexibility does not mean that the limited showing required by Bursey would significantly detract from that interest. The court's argument, moreover, assumes its conclusion. The evil discerned by witnesses results from grand jury investigations that are not particularized. ${ }^{95}$ If the inquest is indeed to ascertain whether a particular crime has been committed by particular persons then the threat to first amendment liberties is minimal and, in the usual case, outweighed by the substantial interest of the grand jury. It would also appear in this situation that the burden to the government of demonstrating relevancy is slight. On the other hand, if the grand jury is

93460 F.2d 328, 331-32 (1st Cir. 1972).

84 Id.

95 The grand jury's traditionally broad range of inquiry means the ability to track down every lead or hunch in connection with specific, or general, criminal activity. It does not mean that grand juries are allowed to call witnesses with no substantial connection to its stated objectives in order to ascertain political affiliations, because this would contradict another purpose of the grand jury: "to stand between the prosecutor and the accused, and to determine whether the charge was founded upon credible testimony or was dictated by malice or personal ill will." Hale v. Henkel, 201 U.S. 43, 59 (1906) (expounding the traditional English doctrine). 
inquiring into the affairs of a dissident newspaper or political party without really attempting to discover criminal activity, then the interests in free press and association call for protection. Only then would it be difficult for the grand jury to make its showing.

Legislative committees, it is argued, are more susceptible to abusing witnesses' rights because they, unlike grand juries, respond almost entirely to political pressures. ${ }^{90}$ The extensive control exercised by the prosecutor, who is invariably politically sensitive, over the grand jury belies this assumption. The argument may cut the other way since the ultimate political accountability of the legislature may restrain its repressive investigations. To the extent the contention has validity, it ought not to afford a sufficient basis to justify treating the two bodies differently, because, politics notwithstanding, the exercise of first amendment rights has been stifled equivalently.

The court in Doe also raised the point that even a limited showing of relevancy would undermine the long-standing policy of grand jury secrecy. ${ }^{97}$ Previously, we have seen that the justifications for secrecy are not persuasive when a witness seeks access to his own testimony. The same is true here. ${ }^{98}$ The showing would occur only after the questions had been asked (possibly after a contempt citation), and therefore the witness would already have a good idea what suspects the grand jury had in mind. The testimony of other witnesses or the discussions of grand jurors could perhaps be placed in summary form so that they could not be recognized. Or, names could be excised from the transcript. If necessary, the relevancy showing could be made in camera. In sum, the arguments based on the functional differences of the two bodies against applying the legislative investigation test to grand juries are not persuasive.

One reason the Bursey test does not unduly hinder the grand jury's operations is that it does not act as a substantive bar to its obtaining information. It requires the investigation to follow a procedural path so that questions necessary to the inquest will interfere as slightly as possible with first amendment interests. Certainly, several individuals could not begin publishing a newspaper, commit a crime, and when questioned about their co-conspirators' participation remain silent behind an assertion of their right to publish anonymously ${ }^{99}$ But this is not what took place in Bursey. First, the existence of a crime had not been established; that was the grand jury's task. Second, assuming a crime had been committed, there was no indication that disclosure of the identities of the members of the newspaper staff or of the Black Panther Party would reveal anyone connected with the crime. The

96 Cf. Grand Jury Investigation, supra note 3 , at 481 .

97460 F.2d at 332.

88466 F.2d at 1091-92 (opinion on petition for rehearing and suggestion for rehearing en banc).

99 Cf. Branzburg v. Hayes, 408 U.S. 665, 705 n.40 (1972) (plurality opinion). 
Ninth Circuit's test did not thwart the grand jury's objectives but simply stopped it from encroaching upon first amendment interests until and unless it was proven necessary. In this respect the opinion imposes less of a constraint on governmental activity than the invalidation of the ordinance in Talley. ${ }^{100}$ If the grand jury showed "that there is a substantial possibility that the information sought will expose criminal activity"101 on the part of the members of the group, then the questions would have to be answered.

Applying its test to the facts before it, ${ }^{102}$ the court had little difficulty finding a substantial governmental interest in investigating possible plots to assassinate the President or to interfere with the armed forces. More refined analysis, however, was required to determine, as the government argued, whether valid governmental objectives outweighed the first amendment interests threatened by the grand jury's questions. For this purpose, questions asked of Bursey and Presley were separated into four groups. Queries intended to discover more about the leaders of the Panther Party and its connection with foreign governments were first considered. In order to investigate whether illegal conspiracies existed, the grand jury needed to ascertain whether the "We will kill Richard Nixon" speech had meaning or was merely rhetorical. To this end it could proceed a step at a time by asking preliminary questions to unearth the identities of those on the Panther Central Committee with whom Hilliard was most likely to have been in contact. The court was also unprepared to say that, if a plot existed, foreign governments would not have been involved. Consequently, eliciting information about possible ties between the Panthers and foreign governments was not impermissible.

In contrast, no legitimate foundation was found for the grand jury's questions about the production and distribution of the Panther newspaper and pamphlets and the identities of those responsible for them. The court began by noting the theories under which the printers, publishers, and distributors of Hilliard's speech and Cleaver's article could be held guilty.

(1) the act of printing, publishing, or distributing these materials was itself criminal, (2) the printers, publishers, and distributors were the "we" to whom Hilliard referred in his speech, and (3) the actors were directly or vicariously responsible for Hilliard's and Cleaver's expressions which were criminal. ${ }^{103}$

Of these, the court focused mainly on discrediting the first. For the act of printing Hilliard's speech to be criminal under the statutes in-

100 See text accompanying notes 84-88 supra.

101466 F.2d at 1083.

102 Id. at 1086-88.

103 Id. at 1087. 
volved, those working on its publication must have possessed specific intent. No evidence was adduced by the government to demonstrate that the editors of the Panther paper had that specific intent, while other newspapermen across the country carrying the same speech did not. The government argued next that the publishers' highlighting of the article evidenced the requisite specific intent. The court refused to accept an inference of specific intent arising from the exercise of editorial judgment by itself. If a decision as to newsworthiness could afford a basis for grand jury investigations, virtually every domestic newspaper could be compelled to reveal the identities of its staff members, the paper's financing, and its inner operations. This result, the court found, is inconsistent with the first amendment. As to the other possible theories of criminal liability, no evidence of actions other than turning out a newspaper was in the record, and publishing a newspaper could not by itself be a predicate for criminal liability.

The third category contained questions seeking the names of workers on the Panther newspaper who appeared in a magazine photograph. Indirect attempts to obtain a list of members of the newspaper staff could not succeed, absent a legitimate foundation, where direct efforts had been forbidden by the court. Finally, broad-gauged inquiries into the financial affairs of the newspaper and the Black Panther Party failed, even though some information from them might be relevant to the grand jury's inquiry, because more sharply focused questions could have uncovered identical information without revealing other information invading the witnesses' privacy.

The court's distinction between questions going to the existence of an alleged plot and those seeking to discover the workings of the newspaper is a valid one and offers a clear illustration of how legitimate and illegitimate grand jury inquiries can be segregated. In light of the seriousness of the possible crime, the court cannot be faulted for making the preliminary assumption that the grand jury's investigation was justified. ${ }^{104}$ Although traditionally assassins have operated somewhat more covertly than Hilliard did in Golden Gate Park, the court probably was deferring to the United States Attorney's office and the fact that it, not the court, initiates grand jury investigations. If the plot were real, those most likely to be involved were the other members of the Black Panther Central Committee, Hilliard's closest associates. The possibility that foreign governments were aiding the Panthers in this plot is more tenuous, but the grand jury can reasonably be permitted to pose questions about this subject, because no countervailing first amendment right of association could convincingly be invoked by the Panthers. Although if they were financed from abroad, questions into the nature of the sponsors could substantially harm the organiza-

104 The court expressly disclaimed any opinion as to whether or not the speech was "a kind of crude political hyperbole." Id. at 1067 n.1. 
tion, nevertheless, this danger to the party would be outweighed by the legitimate governmental interest in preventing foreign subversion of the United States. However, when posing questions about the operations of the Panther newspaper and the identity of its staff, the grand jury was embarking on a fishing trip. No explanation was offered to justify believing that the people associated with the paper should be the "We" to whom Hilliard referred. Moreover, permitting these questions could seriously damage the ability of the Panthers to publish and to attract and retain members. When the first amendment rights of association and press were weighed against the highly attenuated relationship between the grand jury's questions and the subject matter of the investigation, the outcome for a court should be obvious.

That the Bursey court adopted its standard before the Supreme Court decided Branzburg v. Hayes ${ }^{105}$ casts some doubt upon the viability of the Ninth Circuit's test. Branzburg held that the first amendment did not create a qualified privilege for newsmen by requiring that the grand jury make a preliminary showing of need and relevancy before they could be asked to reveal confidential sources. Judge Hufstedler offered several reasons for rejecting the government's argument that the rationale of Branzburg was inconsistent with Bursey's reasoning and result. ${ }^{106}$ First, where the asserted constitutional interest in Branzburg was the ability of the press effectively to gather news, Bursey involved both the need to publish anonymously and associational interests. Second, no claim for a preliminary showing by the grand jury was asserted in Bursey. The limited showing asked of the government came into operation only after an individual demonstrated his first amendment rights needed protection and during a contempt hearing in court. Third, the test did not act as a substantive bar to the grand jury's obtaining information. It demanded simply that the questioning occur with the minimum adverse impact on first amendment interests. Finally, the court recognized that broad language in Branzburg might intimate that the government's interest in grand juries, absent bad faith or harassment, would invariably outweigh first amendment liberties. The court, however, refused to accept this implication.

No one could argue that the constraints on first amendment interests in Bursey were not more real than the ones in Branzburg Justice White found so speculative. ${ }^{107}$ Likewise, the burden on grand jury procedure is not so great as would have been imposed by a constitutional newsman privilege. The protection would be available to newsmen and non-newsmen alike, although the existence of a press interest would be a factor in favor of applying the test. ${ }^{108}$ Associational interests by

105408 U.S. 665 (1972).

106466 F.2d at 1090-91 (opinion on petition for rehearing and suggestion for rehearing en banc).

107408 U.S. at $690-95$.

108 Id. at $687-90,697-98$. Justice White stressed the fact that newsmen were not 
themselves could trigger the adoption of the test in certain circumstances. ${ }^{109}$

The crucial question remains of what, in light of the infringement of first amendment liberties, is necessary for the grand jury in fulfilling its valid objectives. Justice White, writing for the plurality in Branzburg, took an extremely liberal view of the needs of the grand jury. It is not bound by strict standards of materiality or relevance, but is free to conduct its broad inquiry according to its own assessment of its need for information. Primarily on this basis the Court rejected the qualified newsman privilege. ${ }^{110}$

White's biased balancing also produces uncertainty with respect to Bursey's first amendment test. Although his categorizing the first amendment interests as speculative can be challenged, ${ }^{111}$ that is not the real problem with his test. $\mathrm{He}$ incorrectly describes the governmental interests at issue. To him "the investigation of crime by the grand jury implements a fundamental governmental role of securing the safety of the person and the property of the citizen."112 Of course no one would quarrel with such a statement. The more precise question is whether the government's interest in a particular means of furthering that objective, that is, a grand jury investigation without a newsman privilege, would be unduly threatened. The latter interpretation of the requirements of the grand jury is not altogether at variance with the court's resolution in Bursey. Judge Hufstedler was more concerned with any possible loss in effectiveness suffered by the grand jury as a result of the adoption of the proposed test. She concluded the loss was minimal.

Assuming for the sake of argument that the rationale of Branzburg is inconsistent with the reasoning in Bursey, there are two hopes for the survival of Bursey's first amendment holding. ${ }^{113}$ The Supreme Court may use a more refined balancing test when confronted with a different claim for protecting first amendment interests during a grand jury investigation. Instead of loosely placing on the government's side of the equation its interest in combatting crime, it may focus more accurately on the government's interest in pursuing that end through the means actually at issue. Formulating the test thusly would certainly tip the scales less favorably and artificially in favor of the government.

White's opinion in Branzburg also left open the possibility that in certain situations the Court would require the grand jury to state its reasons for calling reporters. This would occur only in a narrow set of

to be treated differently from ordinary citizens either with respect to their duty to give information to the grand jury or with respect to their relationship with informers or criminals.

109 Cf. United States v. Weinberg, 439 F.2d 743, 750 (9th Cir. 1971).

110 The Supreme Court, 1971 Term, 86 HARv. L. Rev. 50, 143 (1972).

111408 U.S. at 728-33 (Stewart, J., dissenting).

112 Id. at 700 .

113 Bursey has received some judicial approval. United States v. Liddy, No. 72-2210, at 4 (D.C. Cir., Dec. 20, 1972) (per curiam) (Leventhal, J., concurring). 
circumstances when grand jury investigations were begun or conducted in bad faith or to harass the press. ${ }^{114}$ Justice White's formulation seemed to imply that the burden of proving the government's bad faith would be placed on newsmen. Such a hurdle might well be insurmountable, especially in light of White's emphasis on the grand jury's need for flexibility in conducting its own investigation. ${ }^{115}$ Justice Powell in a cryptic concurrence ${ }^{116}$ appeared to construe this "bad faith" exception more expansively. ${ }^{117} \mathrm{~A}$ newsman was entitled to judicial protection if he had been

called upon to give information bearing only a remote and tenuous relationship to the subject of the investigation, or if he has some other reason to believe that his testimony implicates confidential source relationships without a legitimate need of law enforcement. ${ }^{118}$

Although neither articulation of the test was clear, Powell's version ${ }^{110}$ might give lower federal courts some leeway when confronted with claims, similar to those in Bursey, that first amendment interests were threatened in the course of a grand jury investigation.

114408 U.S. at 707-08.

115 Id. at 701-02.

$116 I d$. at 709-10. His was the fifth vote necessary for a majority. He indicated that it was the court's duty to balance the conflicting interests, thereby implying that neither side would have the burden of proof. $I d$. at $710 \mathrm{n}$.*.

117 Cf. The Supreme Court, 1971 Term, 86 HaRv. L. Rev. 50, 144-45 (1972).

118408 U.S. at 710.

119 In order for Powell's test to have growing power, it would be necessary not to read narrowly his reference to "newsman," but to consider any person, whose first amendment interests are threatened, as entitled to protection. 